\title{
The Possibility of Applying the Ship Arrest Measure in Case of Intellectual Property Infringement
}

\section{Mogućnost primjene mjere zaustavljanja broda u slučaju povrede prava intelektualnog vlasništva}

\author{
Moreno Pajković \\ Odvjetnički ured Sanjin Jurmić \\ Rijeka \\ e-mail:mpajkovic.mi@outlook.com
}

\author{
DOI 10.17818/NM/2020/2.8 \\ UDK 347.79:341.225.5 \\ Review / Pregledni rad \\ Paper accepted / Rukopis primljen: 19. 11. 2019.
}

\begin{abstract}
Summary
While researching various issues and peculiarities of intellectual property in the marine environment and the industry that coincides, the author started to contemplate on the possibility of applying the provisional measure of ship arrest as means of achieving potentially positive outcome for an intellectual property holder falling victim to infringement of his rights. This approach may be considered more as a preliminary measure that - by exerting pressure upon the ship-operator (or owner) to eliminate the infringement - might lead to a potential relief by way of settlement, rather than applying the conventional remedies. To this end, the paper will examine the possibility of applying alternative means of intellectual property protection in the unique maritime regulatory environment. In doing so, the question of whether or not an intellectual property infringement claim may be qualified as a maritime claim will be also addressed as it represents one of the crucial prerequisites to applying the ship arrest measure in these particular circumstances. The application of this rather unconventional intellectual property protection measure will start from the Croatian ship arrest and release procedure and rules followed by the appropriate rules of international law as well.
\end{abstract}

\begin{abstract}
Sažetak
Istražujući raznolika pitanja i posebnosti intelektualnog vlasništva u pomorskom okruženju i pratećoj industriji, autor je počeo promišljati o mogućnosti primjene privremene mjere zaustavljanja broda kao načina postizanja potencijalno pozitivnog ishoda za nositelja prava intelektualnog vlasništva koji postaje žrtva povrede spomenutoga prava. Ovaj pristup može se smatrati više preliminarnom mjerom, koja bi - vršeći pritisak na brodara (ili vlasnika) da otkloni povredu - mogla dovesti do potencijalnog olakšanja sklapanjem nagodbe, umjesto primjene uobičajenih pravnih lijekova. $U$ tom smislu, u radu će se ispitati mogućnost primjene alternativnih sredstava zaštite prava intelektualnog vlasništva u jedinstvenom pomorskom regulatornom okruženju. Pritom će se razmatrati i pitanje može li se tražbina za povredu prava intelektualnog vlasništva kvalificirati kao pomorska tražbina jer predstavlja jedan od ključnih preduvjeta primjene mjere zadržavanja broda u ovim posebnim okolnostima. U primjeni ove prilično nekonvencionalne mjere zaštite prava intelektualnog vlasništva polaziti će se od hrvatskih procesnih pravila o zaustavljanju broda, uključujući pritom $i$ odgovarajuća pravila međunarodnog prava.
\end{abstract}

\section{KEY WORDS}

provisional measure of ship arrest maritime claim

patent

industrial design

intellectual property

vessel

ship

yacht

accidental entry

temporary entry

\section{RESEARCH PROBLEM, OBJECTIVES AND METHODLOGY / Problem, ciljevi i metodologija istraživanja}

The issues of intellectual property (hereinafter: IP) in maritime law seem generally overlooked. However, in the age of growing technological advancements IP is becoming an inseparable part of maritime law. In an industry that is no stranger to fetes of engineering, maritime-oriented companies find this material area of law indispensable. Autonomous watercrafts such as ships and submersibles, artificial intelligence, marine bioprospecting, following, trustworthy technologies transaction systems (alias blockchain) including likewise green technologies - such as various waste management systems and devices as well as alternative propulsion systems - are just some of the examples that draw upon the importance of IP in the marine sector of the economy. From various methods to inventions, drawings and designs - all are covered by some type of IP protection, be it patent, industrial design, trademark, copyright (i.e. author's right) and other comparative-legal protection varieties found thereat. 
Technologies and equipment that are built in during the construction of the vessel or concern the construction itself, makes any further discussion here redundant since infringements related to this particular phase may easily be addressed. In that regard, Mikalsen et al. ${ }^{1}$ even suggest strategic options for patents, which include protecting the invention in places such as: major shipbuilding countries; areas of operation and the territory of the major ports of the world; and finally protecting the invention in the flag state of a ship (vessels).

However, there are certain inventions that may not feature such a simplistic approach. Namely, various components, smaller equipment or tools and even software-based inventions may be much harder to protect as they do not have to necessarily be supplied from the shipyard, but installed at sea while being supplied from a country that lacks a strong IP protection system or otherwise a country where a particular IP had not been registered. ${ }^{2}$ As an even more complex example, Mikalsen even mentions method patents which may only be infringed when the method is actually in use. ${ }^{3}$

The problem, of course, occurs when the effect of IP protection laws are found to be restricted in regards to either the location of the vessel or the immunity status the vessel disposes of when entering a port - as will be elaborated further in the paper.

The obvious problem that follows - likewise noticed by Mikalsen - is that a lack of sufficient and effective IP protection may negatively reflect on research and development of new solutions. However, while this surprisingly seems as an even greater problem when considering petroleum rigs (both stationary and mobile) operating offshore, the problem that occurs in relation to other vessels such as ships and yachts entering the territorial waters of a country and its ports seems more opportunistic. Especially when considering the type of IP that may be concerned in these circumstances.

Therefore, this paper will analyze the possibility of applying a ship arrest measure as a new means of achieving compensation for IP infringements. This possibility will be examined from the perspective of Croatian legislation including thereat the international legal instruments as well - given the international nature of the subject involved. Considering that the matter requires an examination of the legal nature and concept of the maritime claim, the paper will address this as well to determine whether or not (and to what extent) the possibility of subsuming an IP infringement claim under the aforesaid concept exists.

This unconventional approach may be considered more of a preliminary measure that seeks to eliminate the infringement by exerting pressure upon the ship-operator (or owner) leading possibly to a potential relief via settlement, rather then applying the conventional remedies and venturing on a lengthy legal proceeding.

Finally, although, the hypothesis of this paper is that an IP infringement may be treated as a maritime claim, hence allowing the appliance of a ship arrest measure, the idea of applying such a measure is nonetheless confined only to a theoretical possibility, while the practicality and probability

${ }^{1}$ Mikalsen, Rikard, Harlfinger, Philipp, Roskilly P. Anthony, Patent protection in the marine industry: international legal framework and strategic options, Proceedings of the Institution of Mechanical Engineers (Proc. ImechE), Part M: Journal of Engineering for the Maritime Environment, Vol. 225, Issue 3, 2011, p. 6-8

2 Likwise, ibid., p. 8-9; Mikalsen, Rikard, Patent protection on petroleum vessels, LLM thesis, Newcastle University, UK, 2016, p. 16-17, accessible: http://www. mikalsen.eu/files/LLMthesis.pdf

${ }^{3}$ See example: Mikalsen, Rikard, Patent protection on petroleum vessels..., p. 11-12 of reaching for it in these particular IP circumstances remains debatable.

\section{PROVISIONAL MEASURE OF SHIP ARREST / Privremena mjera zaustavljanja broda}

\subsection{Generalities / Opća načela}

The arrest of ship must firstly be distinguished in relation to detention of a ship. Namely, detention of a ship signifies the power of a public body to forcefully hold a ship in port because of significant or multiple deficiencies in terms of compliance with certain standards, i.e. breaches of certain public or administrative legal regulations. For example, due to a violation of regulations in the area of maritime ecology law (i.e. potential sea pollution) the Port State Control (PSC), or the authorized inspector of the Port Authority, has the power to prohibit the ship from leaving and impose the appropriate fine. ${ }^{4}$ Likewise, the forcible detention of a ship in a port may also be designated by the Criminal Court during a criminal procedure and by the Customs Administration as well, if it establishes the merits of such a measure in the customs procedure.

Here, a distinction should be made with respect to ship seizure which in Croatia has a broader meaning depending on whether it is a prevailing time of peace or time of war. In a time of war this power has the significance of ship capture ${ }^{5}$ and its confiscation, whereas in a time of peace it generally represents the power of public authorities to halt, search and ultimately seize (alias residual rights) a ship if there is reasonable doubt that the ship is engaged in piracy, trade or transport of slaves or there is a suspicion that a ship is without nationality, etc. ${ }^{6}$

Ship arrest, on the other hand, as a measure o security which takes a special place in maritime procedural law ${ }^{7}$, represents such a measure available at disposal of private-legal entities.

The main characteristic of ship arrest (arrestationem navis) is a judicial decision prohibiting the departure of a ship from the port in which it is currently located ${ }^{8}$, in order to secure legally based claims of the applicant. ${ }^{9}$ By legal nature, it is a measure of conservational character ${ }^{10}$ whose primary purpose is - given

${ }^{4}$ Vuković, Ante, Bodul, Dejan, Ship Arrest in the Croatian Law - de lege lata and de lege ferenda solutions -, Comparative Maritime Law, Vol. 51, No. 166, 2012, p. 259; See more on ship detention: Gagro, Fabijanić, Sandra, Division of Rights and Obligations According to the UN Convention on the Law of the Sea in the Case of Pollution of the Maritime Environment, Collection of Papers, Faculty of Law Split, Vol. 45, No. 2, 2008, p. 416-425

${ }^{5}$ In the case Andersen v. Marten [1907] 2 K.B. 253 for the needs of maritime insurance law the term capture presumes: "(...) ships and cargoes-were (and still are) properly treated as objects of war to be taken in prize or by way of reprisal: this was the meaning of the word capture (...)". See more on the relevant terminology: Pavić, Drago, Insuring War Risks, Collection of Papers, Faculty of Law of Split (CPFLS), Split, yr. 46, 3/2009

${ }^{6}$ See more: Degan, D. Đuro, International Law of the Sea in Peacetime and in Armed Conflicts, Faculty of Law, University of Rijeka, Rijeka, 2002, p. 84-86

${ }^{7}$ Maritime procedural law encompasses norms relating to the special jurisdiction of bodies and procedures for the application of property-legal, administrative and criminal regulations of maritime law (Ćizmić, 2006:14). According to Ćizmić, the maritime procedural law matter would broadly cover the rules for dealing with maritime controversies and the jurisdiction of the courts resolving controversies to which maritime law applies, different from the procedures applicable for resolving other controversies; on the procedure of general average liquidation; on the procedure for enrolment in the register of watercrafts; ship-operator's liability limitation procedure; specific rules on ship and cargo enforcement including security measures as well. See more: Čizmić, Jozo, Croatian Maritime Procedure Law, Faculty of Law, University of Split, Split, 2006

${ }^{8}$ Art.952, Croatian Maritime Code, OG no. 181/04, 76/07, 146/08, 61/11, 56/13, 26/15, 17/19 (consolidated text) (hereinafter: CMC

${ }^{9}$ Marin, Jasenko, Provisional Arrest of a Ship, Faculty of Law, University of Zagreb, Zagreb, 2003, p. 8

${ }^{10}$ In addition to the conservational character, in the legal theory prof. M. Dika defined the interim measures by distinguishing its anticipatory and regulatory function; see more Marin, Jasenko, op. cit., p. 6, reference 15 
that very function - to ensure the future satisfaction of the applicant's claim. ${ }^{11}$

Given the nomen iuris of this measure, its temporal feature is likewise highly indicative as it manifests in the time-limited or temporary duration of such a measure, in other words, it cannot last indefinitely. As the measure of a temporary ship arrest may be proposed until the enforcement is carried out ${ }^{12}$, it leads to the conclusion of how the endpoint for the duration of this measure extends up till the moment of enforcement execution. ${ }^{13}$ Regardless of this, the writ by which such a measure is to be imposed must also specify the period of its duration, which may be determined in the minimum duration of the statutory (preclusive) period of 15 days and even until the final conclusion of the dispute..$^{14}$ If the measure were to be imposed for a minimum period of 15 days, the court may, at the proposal of a party with a legal interest (if it is proposed before the expiry of that period) extend the duration of the measure provided that the conditions under which that measure has been issued remain unchanged.

Such a measure, from a comparative law perspective, is often carried out by specialized courts overseeing maritime disputes (so-called maritime courts; admiralty courts) or commercial courts as is the case in Croatia..$^{15}$ Thus, in Croatia, the procedure of obtaining security by imposing the measure in question is carried out by the Commercial Courts which, in their composition have offices presided over by judges specializing in maritime law. These include the First Instance Commercial Court in Split and Rijeka ${ }^{16}$ with the High Commercial Court in Zagreb as a court of a higher instance, i.e. a second instance court or the appellate court. ${ }^{17}$

The measure of provisional ship arrest may be proposed before initiating or during a civil, enforcement or administrative procedure $^{18}$ and upon completion of these procedures ${ }^{19}$. It should be noted how this is not a self-contained and independent measure, but it is a measure that builds upon another judicial or administrative procedure where the court or other oversight body decides on the merits of the case. According to the above, if the same measure is issued before the initiation of the appropriate procedure, then the applicant's

\footnotetext{
${ }^{11}$ Marin, Jasenko, Provisional Arrest..., p. 12

${ }^{12}$ Vuković, Ante, Bodul, Dejan, op. cit., p. 264

${ }^{13}$ See: ibid., p. 266 and Art.341, §1, CMC

${ }^{14}$ Vuković, Ante, Bodul, Dejan, op. cit., p. 266-267

${ }^{15}$ In contrast, it is interesting to mention how an Intellectual Property and International Trade Court (IP\&IT Court) had been established in the Kingdom of Thailand which applies a unique common law approach to solving the civil law problem. In addition, within the framework of resolving mostly disputes arising out of intellectual property rights and maritime disputes, it is exclusively competent for deciding on the temporary ship arrest measures.

${ }^{16} \mathrm{It}$ is worth mentioning how Rijeka - as a port city - generally has a long practice and experience in resolving maritime disputes dating back to the time when the Maritime arbitration in Sušak was active, concurrently being the first example of maritime arbitration in Croatia (Hlača, 2001:427). In addition, the city of Rijeka, with its vibrant commercial activity, also housed the Maritime Court in Sušak, which in fact was the district court competent over maritime affairs and disputes emanating from maritime and other maritime commercial affairs, with The Court of Appeal in Zagreb (Hlača, 2001:436). In such circumstances, the city of Rijeka has undoubtedly had not only an abundance of normative acts in the area of autonomous maritime regulation, but also an abundant court practice established by the decisions of maritime courts; see more: Hlača, Vinko, O nekim pitanjima pomorskog sudovanja i arbitraže na Sušaku, Croatian maritime law - selected papers, Faculty of Law, University of Rijeka, Rijeka, 2001, p. 427-445; likewise: Bartulović, Željko, From history of international status of Rijeka's port, Collection of Papers, Faculty of Law of the University of Mostar, (1029-4031) XVI (2003); p. 249-264 in extens

${ }^{17}$ Art.7, Act on Areas and Seats of the Courts, OG no. 67/18

${ }^{18}$ Art.951, §1, CMC

${ }^{19}$ Vuković, Ante, Bodul, Dejan, op. cit., p. 261
}

duty will be to prove that the appropriate judicial or arbitral proceedings on the merits of the case have been initiated. The applicant's duty to commence such proceedings and notify the curt thereof must be fulfilled within 15 days from the delivery of the Provisional Measure Order.

Consequently, the interested party will likely be able to obtain a provisional measure if he subsequently proves to the court that appropriate proceedings for resolving the merits relating to the IP infringement have been initiated, irrespective of whether that case is being resolved in the country in question or abroad.

\subsection{Conditions for application / Uvjeti primjene}

The measure of provisional ship arrest may be directed only towards a vessel located in the harbor even when it is ready to sail (Fr. prêt a faire voile) and as long as it does not ancoras tollere. ${ }^{20}$ This is consistent with the provisions of Art. 28 of the United Nations Convention on the Law of the Sea (hereinafter: UNCLOS), which gives the States the possibility of executing their civil jurisdiction in full in relation to foreign ships entering or exiting its ports as well as for the obligations incurred in the port by either the ship-operator (i.e. the ship-owner) or the ship. The measures of detention, enforcement and sale of the vessel are likewise not excluded in this case.

In addition, the aforementioned provision provides for the possibility of coastal State's civil jurisdiction to be executed with respect to obligations and responsibilities incurred outside its waters as well, provided, of course, that the relevant vessel stops or anchors in its territorial sea (hereinafter: TS) or inner sea waters (hereinafter: ISW). If such stops are not incidental to ordinary navigation or are rendered necessary by force majeure or distress; or even for the purpose of rendering assistance to persons, ships or aircraft in danger or distress ${ }^{21}$; then civil jurisdiction in regards to obligations and responsibilities incurred may not be exercised.

In addition to the above-mentioned cases involving the socalled innocent passage, civil jurisdiction is limited towards ships in transit passage and archipelagic passage; therefore a coastal state must not halt a passing ship nor undertake enforcement measures due to obligations incurred beyond that passage. However, if the ship stops during transit passage it falls within the jurisdiction of the relevant state, but only with regard to the ship's activities related to the passage itself.

Having said this, obviously no measure of ship arrest may, therefore, be imposed beyond the circumstances described above, except in specific instances when the ship in question enters the relevant areas of the costal state - or more specifically - its ports. This is the exact moment when the measure may be undertaken, but whether it can be undertaken and to what extent with respect to infringement of IP is a more difficult question as it depends not only on the practical probability, but the relevant laws that regulate intellectual property (see more infra. III.2.).

Finally, the basic question that can be raised in the context of this paper and the presented opportunity of using the relevant measure in specific circumstances is: whether the purpose of securing the future satisfaction of the applicant's claim - in a context where a dispute revolves around an infringement of

${ }^{20}$ The type of vessel to which the measure may be focused with regard to the type of claim and the law to be applied see more infra. III. 1. 2

${ }^{21}$ Art.18, §2, UNCLOS 
maritime-oriented IP - is achievable. The attempt to provide an answer to this question will be made in the further elaboration of this paper.

\section{RELATIONS BETWEEN THE DIFFERENT SYSTEMS OF LEGAL RULES / Odnosi između različitih sustava pravnih pravila}

To answer the above-mentioned question, it is necessary to outline the existing positive law solutions of national and international nature, including likewise their mutual relations. Namely, the provisional measure of ship arrest is regulated by international rules and national legislation. At the international level there are primarily two sources of law:

- The International Convention for the Unification of Certain

Rules relating to the Arrest of Sea-going Ships, 1952

(hereinafter: Convention of '52).

The International Convention on Arrest of Ships, 1999 (hereinafter: Convention of '99). ${ }^{22}$

As evident, two separate convention systems, each with different countries adhering to them; making it quite clear that complete unification on this issue is missing. For this reason, the matter in which provisional ship arrest measure is regulated varies from country to country depending on whether the solutions of the 1952 Convention or the 1999 Convention had been implemented. The aforementioned convention systems do not regulate all areas of the matter in question, but point to the application of the country's law in which the ship was arrested (lex fori). Thus, states may regulate certain issues independently of the conventional solutions. The ship arrest measure is thus specially arranged by national legislation as well. ${ }^{23}$

For example, in China, ship arrest is regulated by Art. 21 to 43 of the Maritime Procedure Law of July 1st 2000, reflecting the rules of the Convention of ' 99 , while, for example, in Italian law, forced execution and precautionary measures of provisional ship arrest are regulated by the Italian Navigation Code (Codice della Navigazione), reflecting the solutions provided for by the Convention of' 52.

The Convention of '99 entered into force on $24^{\text {th }}$ of September 2011 which Croatia has not ratified as it is a member of the Convention of ' 52 , arranging the issue of provisional ship arrest with its Maritime Code ${ }^{24}$. Likewise, regarding that the CMC contains blanket provisions (Art. 841, $\$ 3$ and 5), the measure is also regulated by the provisions of the Execution $\mathrm{Act}^{25}$ with the proper application of the Civil Procedure Act $^{26}$ as well (Vuković, 2012:257).

For the purposes of this paper, the details of the procedural rules on the legal institute of ship arrest will not be dealt with further in depth, yet the only part that will exclusively be examined are the basic rules and the possibility of applying the ship arrest measure in the specific circumstances outlined in this

${ }^{22}$ The Convention entered into force on 14th of September 2011 and includes 11 Member States, namely the Syrian Arab Republic, Spain, Liberia, Latvia, Estonia Ecuador, Congo, Bulgaria, Benin, Algeria, Albania. There are 6 signatories as well: Pakistan, Norway, Finland, Denmark.

${ }^{23}$ See also: Tasić, Zoran, International Convention for the Unification of Certain Rules Relating to the Arrest of Sea.going Ships, 1952 ("The Arrest Convention"): Review of Certain Provisions, Uporedno pomorsko pravo (UPP), Vol. 37, No. 145-148, 1995, p. $172-173$

${ }^{24}$ See reference 8 for meaning.

${ }^{25}$ Enforcement Act, OG no. 112/12, 25/13, 93/14, 55/16, 73/17 (hereinafter: EA)

${ }^{26}$ Civil Procedure Act, OJ SFRY no. 4/77, 36/77, 6/80, 36/80, 43/82, 69/82,

$58 / 84,74 / 87,57 / 89,20 / 90,27 / 90,35 / 91$, and NN 53/91, 91/92, 58/93, 112/99,

$88 / 01,117 / 03,88 / 05,02 / 07,84 / 08,96 / 08,123 / 08,57 / 11,148 / 11,25 / 13,89 / 14$ (hereinafter: CPA) paper. This will also include an examination of the relation between different systems of legal rules concerning the application of the subject measure in correlation with IP infringement. The matter will be approached from the point of view of the Convention rules of both systems including thereat the solutions of the Croatian legal system without entering into the examination of comparative solutions in relation to other countries.

\subsection{Legal sources on ship arrest / Pravni izvori koji se odnose na zaustavljanje broda}

The Convention of ' 52 , in accordance with the provisions of the Croatian Constitution, forms an integral part of the Croatian legal system, and - as an international instrument - it is characterized by legal superiority, hence the primacy of its application in relation to the solutions emanating from the provisions of the CMC.

Although the contents of the CMC solutions are conceptualized on the Convention model, its application is subsidiary, particularly where the Convention's scope of application has been met, making the provisions of the Convention directly applicable. ${ }^{27}$ Following on the previous remarks, it can be concluded that in Croatia - in terms of arranging the ship arrest matter - a dual system of legal sources is in place. This dual system involves the Convention of ' 52 (as an international source of law) and - on the other side - national sources within which (in addition to the EA and the CPA) the CMC especially stands out.

Given the above consideration, further examination will separately approach the solutions of the 1952 Convention and the CMC on the one side, and the 1999 Convention on the other side.

But in order to find an answer to the subject of this paper, our attention will firstly be placed on the applicant's claim with respect to which he may file for security via the provisional measure of ship arrest.

\subsubsection{Maritime claim / Pomorske tražbine}

The applicant's (i.e. claimant's) claim with respect to which he may seek security by requesting an issuance of a temporary ship arrest measure include only those claims that are explicitly stated in the relevant regulation - in this case the CMC and the Conventions of ' 52 and ' 99 . In the context of maritime procedure law, such a claim is known as a maritime claim and is defined by the aforementioned regulations by the enumeration principle.

Maritime Claims are often said to have a tripartite nature ${ }^{28}$, which is manifested through its three aspects or functions, which include: (a) protective function; (b) jurisdictional and (c) security ${ }^{29}$. However, in addition to this, from a civil law legal system's point of view and especially when considering the law of obligations: a claim is in its essence a claimant's (obligee's; Lat. creditor) enforceable right to demand performance (debt, obligation $)^{30}$ which emanates from his subjective right, while a performance (the prestation), as an object (subject matter) of a legal relationship may take the form of either giving, doing, not doing, allowing (i.e. enduring). ${ }^{31}$

\footnotetext{
${ }^{27}$ See generally more on the scope of application: Sajko, Krešimir, Međunarodno privatno pravo, Narodne Novine, Zagreb, 2009, p. 61-62

${ }^{28}$ Jackson, C. David, Enforcement of Maritime Claims, Informa Law from Routledge (4 edition), London/Singapore, 2013, p. 1

${ }^{29}$ See more: Abou-Nigm, Ruiz, Verónica, The Arrest of Ships in Private International Law, Oxford University Press, 2011, p. 8-11

${ }^{30} \mathrm{An}$ obligation is a legal bond (vinculum iuris) by which one or more parties (obligants) are bound to act or refrain from acting.

${ }^{31}$ Slakoper, Zvonimir, Gorenc, Vilim, Law of Obligations - General, Novi informator, Zagreb, 2009, p. 171
} 
In that sense, the prestation, i.e. the performance to be tendered by the respondent (obligor; Lat. debitor) may be not only an act of payment of reward on the grounds of - e.g. a salvage contract - as a direct response to the claimant's right, i.e. claim; but may indeed be any kind of performance which - as a direct or indirect claim - emanates from certain enumerated legal grounds. The question of grounds depends on the rules that apply.

\subsubsection{The Convention of '52 and the CMC / Konvencija iz 1952. i Pomorski zakonik}

As already stated, the claims on the basis of which the applicant may seek security by way of temporary ship arrest measure include only the ones which are explicitly defined by the CMC, i.e. the Convention of ' 52 . Such a claim - known as a maritime claim - is designated by an exhaustive list. In other words, a maritime claim is not expressly defined, but is only determined as a claim conferred by certain enumerated legal grounds. Thus - being a numerus clausu - claims arising from a title not specified by the relevant regulation makes the application of a ship arrest measure impossible. ${ }^{32}$

According to the $\mathrm{CMC}$, a temporary ship arrest measure may be ordered only for claims arising out of:

1) damages caused by the collision of the ship whose arrest is requested or damages caused by this ship in any other way,

2) death or personal injury caused by the ship whose arrest is requested or caused in connection with the employment of that ship,

3) salvage,

4) contract on the employment of a ship whose arrest is requested,

5) general average,

6) towing,

7) pilotage,

8) supply of the ship whose arrest is requested, with goods, materials, supplies, fuel, equipment, including containers, or services made for its maintenance, storage, exploitation or berthing,

9) construction, alteration, repair, equipment, renovation or docking of the ship whose arrest is requested,

10) labour-related rights of the crew,

11) expenditures related to the ship incurred by the captain, shipper, charterer or an agent for the account of the ship or the owner of the ship or the ship-operator,

12) intermediary commission or agency awards owed in relation to the ship.

13) charges and fees for the use of ports ${ }^{33}$, canals, docks and other waterways. ${ }^{34}$

Temporary arrest, in addition to the above mentioned cases, may also be ordered for the purpose of satisfying maritime liens or mortgages on the ship or securities similar to mortgage

However, although being an exhaustive list, the titles encompassed therein are sufficiently broadly set up to allow for a possible interpretation of other types of claims within

\footnotetext{
32 More infra.

${ }^{33}$ See more: Padovan, Adriana Vincenca, Arrest of a yacht in a Croatian court for the purpose of securing a marina operator's claim, Collection of Papers of the 2 nd International Transport and Insurance Law Confernce, INTRANSLAW Zagreb, 2017, Ćorić, Dorotea, Radionov, Nikoleta, Čar, Aleksandra (ed.), Faculty of Law, University of Zagreb, 2017, p. 379-406 in extenso

${ }^{34}$ Art.953, CMC
}

the appropriate categories listed above. ${ }^{35}$ Thus - for example although the claim arising from an IP infringement (relating to a specific vessel and regardless of the form of infringement) is not listed as a maritime claim per se, its meaning may - with adequate appliance of interpretation technique - be subsumed under one of the claims listed. Consequently, it is possible to single out in this regard Art.953, §1 (9) of the CMC, i.e. a claim arising from "construction, alteration, repair, equipment, renovation or docking of the ship whose arrest is requested".

Likewise, when observing the stylization of the 1952 Convention's provision, the same possibility is noted. Namely, according to the provisions of Art.1, §1 of the Convention, "Maritime Claim" means a claim arising from one out of a total of 17 grounds listed from (a) to (q), where the part that mentions "(I) construction, repair or equipment of any ship (...)" may be singled out for the needs of this paper.

Of course, the scope and purpose of the Convention should always be taken in to account when interpreting the same, especially with regard to the possibility of applying the mechanism in question when maritime-oriented IP is concerned. On that note, it is useful to consider travauxpréparatoires or the preparatory works of the 1952 Convention as a supplementary means of interpretation of international instruments as envisaged by Art.32 of the Vienna Convention on the Law of Treaties (VCLT).

Namely, aside from enumerating the grounds for maritime claims, the preparatory works of the 1952 Convention neither mention specific definitions or meanings of maritime claims nor does it provide a more detailed designation on what the grounds for maritime claims would presume. ${ }^{36}$ The content of the preparatory works says nothing about IP, not to mention its individual derivations such as: patent, industrial design, trademark, and copyright (author's right).

However, such circumstances do not constitute a definitive argument that such cases are not encompassed by the 1952 Convention. Namely, although the possibility of qualifying a maritime-oriented IP infringement as a maritime claim is not expressly foreseen either by the Convention or its preparatory works, they likewise do not expressly exclude such a possibility. Moreover, Art.8, $\$ 2$ of the Convention even mentions the

\footnotetext{
${ }^{35}$ For example, in the case Split Port Administration v. PACIFIC SEAWAYS et KAY SHIPPING (Commercial Court in Split, Case No. R1-97/2013) contrary to the security applicant's allegations (the Split Port Administration), the court initially took the view how the claim amounting to $189.840,00$ EUR incurred on the basis of port charges from July 16th 2008 to 17th August 2010 in the period when the securityopponent's ship (the PACIFIC SEAWAYS) was berthed at the Vranjica-Solin basin port area does not constitute a maritime claim under Art.1, §1 (1) of the 1952 Convention as a claim arising from construction, repair or equipment of any ship or dock charges. Following the claimant's appeal, this was subsequently overturned by the High Commercial Court ruling (No. PŽ-6297/13-3) where it was found that the firstinstance court had wrongly concluded how the cost of the port charge does not constitute - in this very case - the maritime claim referred to in 1952 Convention Art.1, $§ 1$ (1), with respect to which a temporary ship arrest measure may be imposed. In addition, this position was asserted again in the first instance proceedings of the Commercial Court in Split (Case No. R1-169/2013) when the ship arrest procedure was restarted on the same basis against the 2nd-securty-opponent: KAY SHIPPING (from the previously conducted proceedings), who is also the owner of the ship from the maritime controversy mentioned. In support of the possibility of interpreting what constitutes a maritime claim one may also reference the case of Single Member First Instance Court of Korinthos 23/1977 [Commercial Law Review, Vol. 28 (1977), p. 95]: in which it was affirmed how a bill of exchange is not included among maritime claims, however, should the bill of exchange be issued to cover a mortgage, then it would fall within the meaning of such claims.

${ }^{36}$ See more: Travaux préparatoires of the 1910 Collision Convention and of the 1952 Arrest Convention, Comite Maritime International (CMI); accessible: https://comitemaritime.org/wp-content/uploads/2018/05/Travaux-Preparatoiresof-the-1910-Collision-Convention-and-of-the-1952-Arrest-Convention.pdf (15.01.2019.)
} 
possibility of arrest of ships of flag states who are not members of the Convention, within the jurisdiction of member states: "in respect of any of the maritime claims enumerated in article 1 or of any other claim for which the law of the Contracting State permits arrest".

Of course, even though the CMC does not expressly provide for the possibility of a ship arrest on the grounds of an IP infringement, it does not mean that such an arrest of ship is not possible through the prism of equipment. Moreover, by negatively interpreting the CMC provision of $\S 1$, Art.953 which proscribes that the "[p]rovisions on the limitation of the temporary ship arrest solely for claims referred to in Paragraphs 1 and 2" (of the article in question) applies to foreign ships "only if reciprocity exists between the state whose flag the ship flies and the Republic of Croatia" - leads to a conclusion of an existing possibility of reaching for a ship arrest measure related to all other claims (regardless of their nature) in cases where reciprocity between Croatia and the appropriate countries does not exist. ${ }^{37}$

It should likewise be noted that there are several different situations of temporary ship arrest possible in Croatia. Namely, with the possibility of arresting any ship regardless of its nationality, the further options in the Republic of Croatia include:

(a) ship arrest of a 1952 Convention member state is possible only with regards to the title of claims (maritime claims) as listed in the 1952 Convention.

(b) ship arrest of a flag state that is not a member of the 1952 Convention, provided that the reciprocal conditions exist, is thus possible under the same treatment reserved for ships of Croatian nationality.

(c) ship arrest of a flag state not a member of the 1952 Convention and without the existence of the reciprocity, is then possible in regards to any claim irrespective of their nature.

\subsubsection{The Convention of '99 / Konvencija iz 1999.}

Observing the provision of Art.1, §1 of the 1999 Convention, "Maritime Claim" in terms of the Convention, means a claim arising out of one or more enumerated grounds referred to from (a) to (v), of which - for the purposes of this paper - (I) and (m) should be singled out.

Namely, the qualification of maritime-oriented IP infringements as a maritime claim seem possible with respect to claims arising from: “(I) (...) goods, materials, provisions, bunkers, equipment (including containers) supplied or services rendered to the ship for its operation, management, preservation or maintenance"; or rather claims arising from " $(m)(.$.$) construction,$ reconstruction, repair, converting or equipping of the ship".

\footnotetext{
${ }^{37}$ Similarly, in the case of Single Member First Instance Court of Piraeus 864/1979 [Maritime Law Review, Vol. 9 (1985), p. 6], the applicant of the security requested an arrest of a ship belonging to the security-opponent on the basis of receivables arising from services provided as a maritime agent to the ship. The Court, in contrast to the security-opponent's allegations, was of a view that the receivables in question were maritime claims under Greek law pursuant to which an arrest of a ship that does not fly the flag of the 1952 Convention member state may carry out when such ship was found within the jurisdiction of a 1952 Convention Member State. Furthermore, in the case of Morsviazsputnik Satellite Communications and Navigational Electronic Aids v. Azov Shipping Company (2001 Dir. Mar. 1113) the second instance court in Genoa affirmed that an arrest of a Ukrainian ship Yuriy Dvuzhilny belonging to the security-opponent Morsviazsputnik S.C. and Navigational E. A. was possible with regard to ships flying the flags of non-member states and in respect of claims that are not even maritime by nature, provided that there is prima facie evidence (fumus boni iuris) of the existence of the claim and danger that the debtor's property (security-opponent) would in the future be inaccessible for the execution of the verdict (periculum in mora).
}

In the first case, the explicit mention of "equipment" and even of "materials" with which the ship was supplied for its operation or maintenance goes in favor of the first case outlined. The possibility of reaching for a claim on the grounds of maritime-oriented IP infringement is even more evident when considering the legal interpretations that appear with respect to the term "operation" (of the ship), i.e. its implicit meaning in relation to the expression "(...) use exclusively for the needs of the vessel (...)" - contained in the international instrument regulating industrial property (more infra. III.2.).

Given that the second case of maritime claim referred to above has already been discussed earlier by examining the solutions of the 1952 Convention and the CMC, all further arguments in this regard are redundant - however - little more attention should be devoted to the stylization of "equipping of the ship". Namely, intellectual property as intangible assets is inherently inseparable from the object it protects, and the protected object, i. e. equipment or other parts or components of the ship is (similar to planka in naufragio) a constituent part of a ship without which it would not be what it is - a ship (navis). It therefore follows that the maritime claim based on "(...) equipment (...)" likewise presumes such claims that are inherent both physically (materially-consistent) and legally to "equipment" and which emanate from it as such.

\subsection{SHIP ARREST IN THE CONTEXT OF THE SYSTEM OF INTELLECTUAL PROPERTY RULES / Zaustavljanje broda u kontekstu prava intelektualnog vlasništva}

The system of IP legal rules likewise distinguishes: international sources of law and national. National are largely a result of ratification of international rules and the implementation of their solutions, of course - as was already brought to attention - variations between different legislations do exist, and not only between the Common law legal tradition and the EuroContinental legal tradition, but also between the various legislations within them. Additionally, the fact of implementing EU law with the possible harmonization exception in regards to directives, the differences are even more apparent.

However, a basic framework does still exists to a certain extent, which is more or less common to a greater number of countries. While the Convention Establishing the World Intellectual Property Organization (WIPO Convention) ${ }^{38}$ and the Agreement on Trade-Related Aspects of Intellectual Property Rights (WTO TRIPS Agreement) may be mentioned as examples, there are numerous other international instruments which include one particularly important for the purposes of this paper: the Paris Convention for the Protection of Industrial Property of 1883 (hereinafter: the Paris Convention).

Further elaboration will therefore start from the Paris Convention, more specifically one of its remarkable provisions, after which similar solutions will be likewise analyzed in the national legislation of Croatia, specifically the $\mathrm{PA}^{39}, \mathrm{TA}^{40}, \mathrm{IDA}^{41}$ and the AARaRR ${ }^{42}$.

\footnotetext{
${ }^{38}$ The Convention is from 1967 , amended 1979

39 Patent Act, OG no. 173/03, 87/05, 76/07, 30/09, 128/10, 49/11, 76/13, 46/18 (hereafter: $\mathrm{PA}$ ).

${ }^{40}$ Trademark Act, OG no. 14/19 (hereinafter: TA)

${ }^{41}$ Industrial Design Act, Official Gazette no. 173/03, 54/05, 76/07, 30/09, 49/11, 46/18 (hereinafter: IDA).

${ }^{42}$ Act on Author's Right and Related Rights, OG no. 167/03, 79/07, 80/11, 125/11, 141/13, 127/14, 62/17, 96/18 (hereinafter: AARaRR).
} 
The aforementioned provision of the Paris Convention is found in Art.5ter [Patents: Patented Devices Forming Part of Vessels, Aircraft, or Land Vehicles] which reads:

"In any country of the Union the following shall not be considered as infringements of the rights of a patentee:

1. the use on board vessels of other countries of the Union of devices forming the subject of his patent in the body of the vessel, in the machinery, tackle, gear and other accessories, when such vessels temporarily or accidentally enter the waters of the said country, provided that such devices are used there exclusively for the needs of the vessel;(...)"

Accordingly, several things are noted from the displayed provision. First of all, the basic meaning manifesting in reality is the effect of excluding patent infringement in respect of those objects embedded in a "vessel" or objects used solely for the needs of that "vessel", with - of course - additional conditions being fulfilled thereat (more infra.).

Secondly, with regard to excluding the effect of patent infringement, it should be separately noted and observed in correlation with the rest of the provision's content (i.e. the additional conditions it imposes); namely that the effect is actualized when the following elements are cumulatively fulfilled:

a) when vessels "temporarily or accidentally enter the waters of the said country";

b) vessels belonging to "countries of the Union"; and

c) the patented objects "are used there exclusively for the needs of the vessel".

Given that Croatia is a member of the Paris Convention, a similar solution is foreseen in its PA, specifically in Art.67 and the provision reads as follows:

"The use of products made in accordance with a protected invention in the construction or equipment of a vessels, aircraft or land vehicles belonging to one of the Member States of the Paris Union or a WTO member shall not be considered a patent infringement when the means of transport is temporarily or accidentally located on the territory of the Republic of Croatia provided that the inbuilt product is used exclusively for the needs of that means of transport."

As can be seen from the Croatian variant, though slightly different stylization, the intent and meaning of the Paris Convention's Art.5ter is faithfully reflected, whereby it is concluded how the exclusion applies only to those patented objects (products) which serve solely for the needs of that means of transport, more specifically, such products that are - judging by the stylization - obviously incorporated "in the construction or equipment" of the relevant means of transport, as its constituent parts. ${ }^{43}$ (more infra.)

Of course, the basic idea of the provisions displayed is not to distort trade, i.e. commercial transport. In other words, they provide an answer to a rhetorical question of: how would the transport industry function if a carrier could potentially face claims for violations of IP rights (in this case patents) wherever he arrives. ${ }^{44}$ This provision, therefore, serves as a kind of immunity from potential lawsuits for patent infringement. However, if the

${ }^{43}$ See more infra. on the meaning of: "use of an object exclusively for the needs of the vessel".

44 Anderson, J. Jonas, Hiding Behind Nationality: The Temporary Presence Exception and Patent Infringement Avoidance, Michigan Telecommunications and Technology Law Review, Vol. 15, Issue 1, 2008, p. 23 provision referred to above applies only to patents, the question arises as to what happens in the case of infringements of other forms of IP. Namely, international instruments that relate, e.g. to industrial designs, trademarks or copyrights do not foresee any similar limitation, i.e. similar immunity. The TRIPS Agreement mentions nothing like that.

The same is true for both trademarks and author's right (i.e. copyright) in the Croatian legal system as it recognizes no similar solutions. However the same cannot be said for industrial design.

Namely - contrary to the above - a similar restriction is foreseen on the EU level by Art. 20, $\$ 2$ of the Regulation on Community ${ }^{45}$ designs, and despite of having direct effect, Croatia has further emphasized this possibility in its domestic legislation on industrial design rights, stating in its IDA:

"(...) the exclusive rights conferred by an industrial design

following its registration shall not be exercised in respect of:

1. The equipment of ships and aircrafts registered in a third country when these temporarily enter the territory (aquatorium) of the Republic of Croatia,

2. The import of spare parts and accessories into the Republic of Croatia for the purpose of repairing such ships and aircrafts,

3. The execution of repairs of such ships and aircrafts." (Art.18, §2)

As is apparent from the provision, certain elements that are comparably found in the earlier mentioned patent-related provisions are not contained, namely the condition that refers to accidental entry of the vessels (ship) into Croatia's aquatorium. However, since accidental entry is most often due to seeking shelter, the same meaning can be found in $\$ 3$ of the outlined provision, i.e. "the execution of repairs of such ships (...)".

Pursuant to what has been said so far, it would be worth concentrating on the meaning of the formulations that are repeatedly mentioned, namely: (a) temporary entry; (b) accidental entry; and (c) use exclusively for the needs of the vessel - as conditions to be met in order for the corresponding ship, i.e. its owner or user, to enjoy immunity from potential negative legal consequences such as ship arrest by reason of intellectual property infringement.

\subsubsection{Conditions for exclusion of intellectual property} infringement / Uvjeti izuzimanja povrede intelektualnog vlasništva In addition to the basic UNCLOS principles and rules on state jurisdiction, there are additional specific restrictions recognizable regarding the detention or arrest of the ship, its enforcement and final sale, supported thereat by a special set of international rules in the field of intellectual property.

For example, although the UNCLOS Convention foresees the stopping or anchoring of a ships in certain circumstances ${ }^{46}$ (which is not incidental to ordinary navigation or are rendered necessary by force majeure ${ }^{47}$ ) as qualifiers for States to exercise their jurisdiction in respect of ships who incurred obligations and responsibilities, the UNCLOS however, does not define what general stopping and anchoring means in regular circumstances and especially in terms of a finished voyage.

\footnotetext{
${ }^{45}$ Council Regulation (EC) No 6/2002 of 12 December 2001 on Community designs, Art.20, 22

${ }^{46}$ In the TS (or in port) as well as the passage of the ship through TS after leaving the ISW.

${ }^{47}$ See supra. and Art.18, §2, UNCLOS
} 
The Paris Convention, however, goes a little further, and supplements the notions of stopping and anchoring with notions of temporary entry or accidental entry. Such legal supplementation of de facto stopping and anchoring of a ship gives a completely different impression of what it means to "stop". Introducing the notion of temporary entry - from the stance of IP infringement, i.e. patent infringement - creates a legal fiction (fictio iuris) which changes the notion of stopping or anchoring of a ship in the territory of the state in such a way as to emphasize its temporal feature (i.e. temporality). In other words, the constant movement or transit of a ship is being feigned. Therefore, from an IP point of view, such a ship has never stopped and is thus in no position to be arrested on the grounds of IP infringement.

Obviously, the existence of a degree of risk for a ship to be arrested on the grounds of IP infringement is noticeable given the very fact that the Paris Convention - and from there the national legal solutions as well - address this real and existing probability by providing an exclusion of patent infringement under specific conditions.

In order for the degree of this probability to be clearly comprehended, one must consider the meaning of the terms: (a) accidental entry; b) temporary entry and (c) use exclusively for the needs of the vessel. In terms of the Paris Convention, the concepts of terms outlined above - of course - are not even marginally defined, so the significance of their interpretation is left to judicial practice, i.e. case law.

(a) Accidental entry is often equated with temporary entry and as Mikalsen et al. explain; regardless of accidental entry as a term not being much of an object of judicial interpretation, some commentators still differentiate it from the term temporary entry. ${ }^{48}$ Obviously, the usual examples of ship's accidental entry - as most of the commentators would agree - is the right to seek refuge in the event of distress ${ }^{49}$ (break downs, fuel deficiency, severe storms) as a form of unplanned visit or a stop..$^{50}$

Although there is not much case law devoted to the meaning of accidental entry, it is not necessary to emphasize how the content of its meaning is quite indicative given that - as Mikalsen et al. point out - the intention of the Paris Convention is certainly not the accidental entry of a ship in country's TS so as to carry out commercial activity. ${ }^{51}$ On the contrary, in that context, the duty of restraining from carrying out any trade activity is actualized, since it is provided for by the provision of the UNCLOS. ${ }^{52}$

Any deviation from this rule would mean that these two significant international instruments are not in conformity. Therefore, the meaning of accidental entry is indisputable. As Mikalsen et al. emphasize, an interpretation of the term where it encompasses all circumstances in which a ship does not leave the country's territory because of dismantlement or being

${ }^{48}$ Mikalsen, Rikard et al., op. cit., p. 5

${ }^{49}$ Art.18, §2, UNCLOS and Art.11 of the International Convention On Salvage, 1989 (hereinafter: Salvage Convention) See likewise in relation to yachts: Petrinović, Ranka; Mandić, Nikola, Can Marinas Qualify as Places of Refuge?, Transactions on Maritime Science (TOMS), Vol. 8, No. 1, 2019, p. 123-131 in extenso

${ }^{50}$ Mikalsen, Rikard et al., op. cit., p. 5

${ }^{51}$ loc. cit.

${ }^{52}$ Art. 18 and Art.39, UNCLOS put out of service is more likely; thus being different in relation to temporary entry. Namely, in terms of time length, accidental entry seems longer or even unlimited in comparison to temporary entry. ${ }^{53}$

(b) Temporary entry, on the other hand, is characterized by somewhat more case law. It likewise implies such a meaning which manifests (in this case) as time-limited entry and stop (transit), compared to accidental entry that may be even unlimited in duration.

Even though defining the time-limit of temporary entry would be quite difficult if not even pretentious, it must in some way be determined. Thus, the time interval of the ship's transit has been reduced to the time needed to realize the sole purpose of participating in international trade after which completion the ship departs to the next destination. ${ }^{54}$

Again, as Mikalsen et al. outline, the interval therefore encompasses the completion of a voyage, turning and the commencement of a new voyage, whereby the commercial purpose of the visit is the main factor and not the time of stay, i.e. stopping or anchoring in the country of destination. ${ }^{55}$

In addition to these features, under case law temporary entry presumes the possibility of regular and frequent entries ${ }^{56}$. However temporary entry does not include such an entry that happens during an international voyage with admixtures of cabotage navigation in between domestic ports. In other words, the immunity effect of temporary entry would be kept by the ship in international navigation even if it entered in more consecutive ports of a particular country, provided of course that it does not carry out commercial activities in those ports in terms of cabotage. ${ }^{57}$

(c) Use exclusively for the needs of the vessel is the last of the conditions provided for in the relevant provision of the Paris Convention and it concerns solely those components, parts and devices protected by a patent. Considering the aforementioned provision, it is obvious how the objects of patent must not only be used exclusively for the needs of the vessel, but must also be "in the body of the vessel", i.e. "in the machinery, tackle, gear and other accessories" or in connection thereto. Thus, the object of a patent must be inherent to the vessel, i.e. make its constituent and integral part.

Such stylization of the provision implies that the object in question must be a type of object whose absence would have obviously rendered the vessel unseaworthy or generally unserviceable. In that sense, immunity would only apply to those parts of the vessel that are of importance to its operation. Of course, different types of vessels will have different needs for corresponding components and devices depending on their purpose. Therefore cruise ships and even mega-

${ }^{53}$ Mikalsen, Rikard et al., op. cit., p. 5

${ }^{54}$ Stena Rederi Aktiebolag (AB) v. Irish Ferries Ltd. [2002] R.P.C. 50 (first instance), para. 75-76; Stena Rederi Aktiebolag (AB) v. Irish Ferries Ltd. [2003] EWCA civ 66; [2003] R.P.C. 36. (second instance)

55 Mikalsen, Rikard et al., op. cit., p. 4

${ }^{56}$ Bodenhausen, H.C. Georg, Guide to the Application of the Paris Convention for the Protection of Industrial Property, United International Bureaux for the Protection of Intellectual Property (BIRPI), Geneva, 1967, p. 83, para. (i); accessible: https://www.wipo.int/publications/en/details.jsp?id=239

${ }^{57}$ Mikalsen, Rikard, Patent protection on petroleum vessels..., p. 69 
yachts will logically have the need for different parts and systems in relation to e.g. chemicals ships and liquefied gases ships. ${ }^{58}$

However, Mikalsen et al. additionally, point out how there are many components and parts for which it is not immediately clear whether they fall under the exclusion of the Paris Convention or not. ${ }^{59}$ So in the spirit of the court's interpretations of the Paris Convention's Art.5ter, they are of an opinion how maintenance and repair tools or - for example - various computer systems for voyage planning and cargo management ${ }^{60}$ are seemingly very likely to fall under the exclusion envisaged by the Paris Convention considering the very fact of being able to qualify them as being used exclusively for the needs of the vessel, regardless of the fact that such tools do not really form an integral part of the vessel. ${ }^{61}$

Moffat, for example, goes even further and says:"(...) [i]t might well be argued that every piece of equipment throughout a ship, whether it be a winch or a can-opener, is employed exclusively for the needs of the ship".62 Therefore, one may ask for example, could a sea bin device on a large yacht or mage-yacht qualify as a device used exclusively for the needs of the vessel.

Thus, Mikalsen et al. rightly asks the question of possible alignment of, for example, various types of entertainment devices (e.g. television, radio, video game consoles etc.) in the crews quarters of every vessel, and in particular cruise ships that feature a wider spectrum of entertainment offers for the passengers, under the qualification of "use exclusively for the needs of the vessel".

\subsubsection{Analysis result / Rezultat analize}

Given the foregoing, it can be concluded how an eventual ship arrest with respect to a claim arising out of an IP infringement would be possible without significant limitations with respect to most forms of IPRs, except for patents and industrial designs for which special restrictions apply. Namely, the possibility of ship arrest in case of patent or industrial design infringement is largely restricted by conditions such as whether the ship accidentally entered the port or not, while an eventual arrest would be possible only at the moment and in the circumstances in which the vessel temporarily entered the state's aquatorium provided that the subject of IP infringement is not simultaneously an object that is used exclusively for the needs of the vessel. By cumulative fulfillment of these two conditions, the possibility of any kind of arrest declines.

In connection with this, it is superfluous to point out that there is no barrier to the possibility of arresting ships of flag states that are not members of the Paris Union or the WTO, since the number of such flag states is obviously non-discernible.

In view of the very ship arrest measure the following may be concluded. Namely, if the obstacles in terms of the foregoing conditions would not exist - depending on whether

\footnotetext{
${ }^{58}$ Bodenhausen, H.C. Georg, op. cit., p. 83; likewise: Mikalsen, Rikard et al., op. cit., p 5; also Mikalsen, Rikard, Patent protection on petroleum vessels..., p. 72

${ }^{59}$ Mikalsen, Rikard et al., op. cit., p. 6

60 See more: Rikard, Mikalsen, Patent Protection of Software-Based Inventions in the Maritime Industry, 10th International Conference on Computer and IT Applications in the Maritime Industries, Berlin, 2-4 May 2011, Hamburg, Technische Universität Hamburg-Harburg, 2011, p. 124-133 in extenso

${ }^{61}$ Mikalsen, Rikard et al., op. cit., p. 6

${ }^{62}$ loc. cit.
}

the claims from IPR infringement were to be interpreted as a maritime claim under conventional and national rules on ship arrest - the question of its applicability increasingly prevails by an affirmative answer. In other words, the ship arrest measure would be possibly applicable in case of maritime-oriented IP infringements.

Although the primary effect and purpose of such a measure would be to exert pressure on the ship-operator (or owner) to eliminate the infringement and compensate the damage, in reality however - considering the practicality and costeffectiveness of reaching for such legal protection - makes its use gradually unlikely for more than one reason.

Namely, in addition to the difficulty of identifying the right moment for taking action (i.e. reaching for such a measure), the likelihood of qualifying the legal situation that would allow for an actualization of a ship arrest is difficult to reach as it depends largely on the interpretation of the courts, i.e. case law.

The inevitable fact is that the immunity from the Paris Convention has been extensively laid out making the use of any legal means of protection with respect to patent infringement seemingly quite uncertain, particularly if one considers the extensive interpretation of the relevant provision. However, if the relevant provision was interpreted restrictively and literally, appropriate legal action for patent infringement may be undertaken with regards to those objects which are not used exclusively for the needs of the vessel, especially those objects that do not constitute its integral part or condition the ship's functionality. All of this makes the possibility of reaching for any kind of legal means in this context a somewhat impossible mission.

Additionally, although such measures might have resulted in obtaining an appropriate guarantee (which the ship-owner has as an available option so as to release his ship), such a measure would only partially cause the desired effect on the side of the applicant of the measure which would possibly last till the moment of the final conclusion of IP litigation. Not to mention how much of a financial burden that would be for the applicant of the measure (the IPR holder) which presume not only ship keeping costs but potentially crew maintenance costs..$^{63}$

The likelihood of applying this measure in reality is therefore questionable and small. However, case law does know of examples where injunction was sought, namely in the case of Caldwellv. Van Vlissingen ${ }^{64}$ from 1851 , admittedly long before the Paris Convention and the institute of temporary entry on which the immunity for IP infringement is based. ${ }^{65}$ Besides this, not many examples in case law were found that would complement this material field of law, except the US Supreme Court case of Brown v. Duschesne ${ }^{66}$ where the stance made in Caldwell v. Van Vlissingen was only reaffirmed: namely, that disturbance of international maritime trade due to IP infringements pertaining to vessels should be avoided.

\footnotetext{
${ }^{63}$ Namely, provided the ship-operator's (ship-owner's) funds were not sufficient to support the crew, the court may order the applicant of the measure to provide down payment of necessary amounts for crew maintenance (CMC, Art. 960.). ${ }^{64}$ Caldwell v. Van Vlissingen, Court of Chancery (1851) 68 Eng. Rep. 571 (Ch.)

${ }^{65}$ The case involved a Dutch ship that regularly sailed for England, where on one occasion it employed a screw propeller patented in England. Van Vlissingen, as the owner of the Dutch ship, argued that his ship did not fall under the jurisdiction of English patent law since the ship was built in Holland, is owned by a Dutch national and was manned by a Dutch crew, however, the court rejected such an argument and granted an injunction against the Dutch ship (Anderson, 2008:7). Given that such legal instruments had the potential of hindering maritime trade, an amendment to the patent law was thereafter quickly promulgated in England restricting patent injunctions against ships when in English ports or waters.

${ }^{66}$ Brown v. Duchesne, 60 U.S. 183 (1856)
} 


\section{CONCLUDING REMARKS / Zaključne napomene}

Following the analysis carried out, an affirmative stance may be taken with regards to the hypothesis of applying the ship arrest measure on the grounds of IP infringement. Of course, the confirmed thesis is only a theoretical possibility, while its application in reality remains questionable for several reasons which can be summarized in three categories; namely the costeffectiveness of applying such a measure, the practicality and the general rationality of applying such a measure.

Besides the Caldwell v. Van Vlissingen example of applying some kind of interim measure for the needs of eliminating IP infringements in respect of a vessel, the author has not managed to find any other example besides the one referenced. To the author's knowledge, recent examples which would attest to the practical possibility of applying the ship arrest measure in the specific IP context seem to be lacking as well.

Considering that contemporary case law has not so long been faced with issues of interpreting the terms of temporary and accidental entry in the Paris Convention's provision of Art.5ter and its national variants, one can only speculate on the meaning of these terms and the general idea of possible ship arrest based on IP infringement. The factual possibility of applying the relevant measure in the context considered therefore remains debatable.

\section{REFERENCES / Literatura}

[1] United Nations Convention on the Law of the Sea, 10 December 1982

[2] Paris Convention for the Protection of Industrial Property, 1883

[3] International Convention for the Unification of Certain Rules relating to the Arrest of Sea-going Ships, 1952 https://doi.org/10.1093/ulr/os-16.2.544

[4] International Convention on Arrest of Ships, 1999

[5] Croatian Maritime Code, OG no. 181/04, 76/07, 146/08, 61/11, 56/13, 26/15, $17 / 19$ (consolidated text)

[6] Patent Act, OG no. 173/03, 87/05, 76/07, 30/09, 128/10, 49/11, 76/13, 46/18

[7] Industrial Design Act, Official Gazette no. 173/03, 54/05, 76/07, 30/09, 49/11, 46/18

[8] Trademark Act, OG no. 14/19

[9] Act on Author's Right and Related Rights, OG no. 167/03, 79/07, 80/11, $125 / 11,141 / 13,127 / 14,62 / 17,96 / 18$

[10] Enforcement Act, OG no. 112/12, 25/13, 93/14, 55/16, 73/17

[11] Civil Procedure Act, OJ SFRY no. 4/77, 36/77, 6/80, 36/80, 43/82, 69/82, 58/84, $74 / 87,57 / 89,20 / 90,27 / 90,35 / 91$, and NN 53/91, 91/92, 58/93, 112/99, 88/01, $117 / 03,88 / 05,02 / 07,84 / 08,96 / 08,123 / 08,57 / 11,148 / 11,25 / 13,89 / 14$. https://doi.org/10.5962/bhl.title.149293

[12] MSC.1/Circ.1343

[13] Act on Areas and Seats of the Courts, OG no. 67/18

[14] Marin, Jasenko, Provisional Arrest of a Ship, Faculty of Law, University of Zagreb, Zagreb, 2003

[15] Dika, Mihajlo, Građansko ovršno pravo, Opće građansko ovršno pravo, Narodne novine, 2007

[16] Adamović, Jasminka; Blažević ,Borislav; Cvetić, Antoneta; Gliha, Igor; Kunda, Ivana; Matanovac, Romana; Matešić, Slavica; Parać, Kamelija; Marinković, Rački Ana; Hrlić, Šiša Marija; Topić, Željko; Vuković, Gordana; Zatezalo, Saša, Prilagodba hrvatskog prava intelektualnog vlasništva europskom pravu, Narodne novine, State Intellectual Property Office, Zagreb, 2007
[17] Bodenhausen, H.C. Georg, Guide to the Application of the Paris Convention for the Protection of Industrial Property, United International Bureaux for the Protection of Intellectual Property (BIRPI), Geneva, 1967

[18] Travaux préparatoires of the 1910 Collision Convention and of the 1952 Arrest Convention, Comite Maritime International (CMI)

[19] Jackson, C. David, Enforcement of Maritime Claims, Informa Law from Routledge (4 edition), London/Singapore, 2013

[20] Abou-Nigm, Ruiz, Verónica, The Arrest of Ships in Private International Law Oxford University Press, 2011

[21] Slakoper, Zvonimir, Gorenc, Vilim, Law of Obligations - General, Novi informator, Zagreb, 2009

[22] Degan, D. Đuro, International Law of the Sea in Peacetime and in Armed Conflicts, Faculty of Law, University of Rijeka, Rijeka, 2002

[23] Attard, J. David, Fitzmaurice, Makgosia, Gutiérrez, M. A. Norman, The IML Manual on International Maritime Law: Volume I: The Law of the Sea, Oxford University Press, 2014

[24] Berlingieri Francesco, Berlingieri on Arrest of Ships: Fifth Edition, Informa Law from Routledge, 2011

[25] Ford, Benjamin, Splash Protection in Practice: The U.S. Vessel Hull Design Protection Act is 13 years old - How is it working for boatbuilders? Professional BoatBuilder, 2012

[26] Olson, Bradley, The Vessel Hull Design Protection Act of 1998: is it still afloat? Journal of Intellectual Property Law \& Practice, Vol. 1, Issue 11, 2006, p. 732739. https://doi.org/10.1093/jiplp/jpl137

[27] Anderson, J. Jonas, Hiding Behind Nationality: The Temporary Presence Exception and Patent Infringement Avoidance, Michigan Telecommunications and Technology Law Review, Vol. 15, Issue 1, 2008

[28] Mikalsen, Rikard, Patent protection on petroleum vessels, LLM thesis, Newcastle University, UK, 2016

[29] Mikalsen, Rikard, Harlfinger, Philipp, Roskilly P. Anthony, Patent protection in the marine industry: international legal framework and strategic options, Proceedings of the Institution of Mechanical Engineers (Proc. ImechE), Part M: Journal of Engineering for the Maritime Environment, Vol. 225, Issue 3, 2011. https://doi.org/10.1177/1475090211410001

[30] Rikard, Mikalsen, Patent Protection of Software-Based Inventions in the Maritime Industry, 10th International Conference on Computer and IT Applications in the Maritime Industries, Berlin, 2-4 May 2011, Hamburg Technische Universität Hamburg-Harburg, 2011

[31] Vuković, Ante, Bodul, Dejan, Ship Arrest in the Croatian Law - de lege lata and de lege ferenda solutions -, Comparative Maritime Law, Vol. 51, No. 166, 2012. https://doi.org/10.5771/9783845297361-154

[32] Padovan, Adriana Vincenca, Arrest of a yacht in a Croatian court for the purpose of securing a marina operator's claim, Collection of Papers of the $2 \mathrm{nd}$ International Transport and Insurance Law Confernce, INTRANSLAW Zagreb, 2017, Ćorić, Dorotea, Radionov, Nikoleta, Čar, Aleksandra (ed.), Faculty of Law, University of Zagreb, 2017

[33] Tasić, Zoran, International Convention for the Unification of Certain Rules Relating to the Arrest of Sea.going Ships, 1952 ("The Arrest Convention"): Review of Certain Provisions, Uporedno pomorsko pravo (UPP), Vol. 37, No. 145-148, 1995. https://doi.org/10.1093/ulr/os-16.2.544

[34] Caldwell v. Van Vlissingen, Court of Chancery (1851) 68 Eng. Rep. 571 (Ch.)

[35] Stena Rederi Aktiebolag (AB) v. Irish Ferries Ltd. [2002] R.P.C. 50 (first instance); Stena Rederi Aktiebolag (AB) v. Irish Ferries Ltd. [2003] EWCA civ 66; [2003] R.P.C. 36. (second instance) https://doi.org/10.1093/rpc/2002rpc50

[36] Port Administration Split v. PACIFIC SEAWAYS et KAY SHIPPING (Commercial Court in Splitu, No. R1-97/2013)

[37] Port Administration Split v. KAY SHIPPING (Commercial Court in Splitu, No. R1-169/2013)

[38] Single Member First Instance Court of Korinthos 23/1977 [Commercial Law Review, Vol. 28 (1977)

[39] Brown v. Duchesne, 60 U.S. 183 (1856)

[40] Single Member First Instance Court of Piraeus 864/1979 [Maritime Law Review, Vol. 9 (1985)

[41] Morsviazsputnik Satellite Communications and Navigational Electronic Aids v. Azov Shipping Company (2001 Dir. Mar. 1113), Court of Appeal of Genoa 12 February 2000 